Palgrave Macmillan Studies in Family and Intimate Life

Titles include:

Graham Allan, Graham Crow and Sheila Hawker

STEPFAMILIES

Harriet Becher

FAMILY PRACTICES IN SOUTH ASIAN MUSLIM FAMILIES

Parenting in a Multi-Faith Britain

Elisa Rose Birch, Anh T. Le and Paul W. Miller

HOUSEHOLD DIVISIONS OF LABOUR

Teamwork, Gender and Time

Ann Buchanan and Anna Rotkirch

FERTILITY RATES AND POPULATION DECLINE

No Time for Children?

Deborah Chambers

SOCIAL MEDIA AND PERSONAL RELATIONSHIPS

Online Intimacies and Networked Friendship

Robbie Duschinsky and Leon Antonio Rocha (editors)

FOUCAULT, THE FAMILY AND POLITICS

Jacqui Gabb

RESEARCHING INTIMACY IN FAMILIES

Stephen Hicks

LESBIAN, GAY AND QUEER PARENTING

Families, Intimacies, Genealogies

Clare Holdsworth

FAMILY AND INTIMATE MOBILITIES

Rachel Hurdley

HOME, MATERIALITY, MEMORY AND BELONGING

Keeping Culture

Peter Jackson (editor)

CHANGING FAMILIES, CHANGING FOOD

Riitta Jallinoja and Eric Widmer (editors)

FAMILIES AND KINSHIP IN CONTEMPORARY EUROPE

Rules and Practices of Relatedness

Lynn Jamieson and Roona Simpson (editors)

LIVING ALONE

Globalization, Identity and Belonging

Lynn Jamieson, Ruth Lewis and Roona Simpson (editors)

RESEARCHING FAMILIES AND RELATIONSHIPS

Reflections on Process

David Morgan

RETHINKING FAMILY PRACTICES 
Petra Nordqvist and Carol Smart

RELATIVE STRANGERS: FAMILY LIFE, GENES AND DONOR CONCEPTION

Eriikka Oinonen

FAMILIES IN CONVERGING EUROPE

A Comparison of Forms, Structures and Ideals

Róisín Ryan-Flood

LESBIAN MOTHERHOOD

Gender, Families and Sexual Citizenship

Sally Sales

ADOPTION, FAMILY AND THE PARADOX OF ORIGINS

A Foucauldian History

Tam Sanger

TRANS PEOPLE'S PARTNERSHIPS

Towards an Ethics of Intimacy

Tam Sanger and Yvette Taylor (editors)

MAPPING INTIMACIES

Relations, Exchanges, Affects

Elizabeth B. Silva

TECHNOLOGY, CULTURE, FAMILY

Influences on Home Life

Lisa Smyth

THE DEMANDS OF MOTHERHOOD

Agents, Roles and Recognitions

Yvette Taylor

EDUCATIONAL DIVERSITY

The Subject of Difference and Different Subjects

Katherine Twamley

LOVE, MARRIAGE AND INTIMACY AMONG GUJARATI INDIANS

A Suitable Match

Palgrave Macmillan Studies in Family and Intimate Life

Series Standing Order ISBN 978-0-230-51748-6 hardback

978-0-230-24924-0 paperback

(outside North America only)

You can receive future titles in this series as they are published by placing a standing order. Please contact your bookseller or, in case of difficulty, write to us at the address below with your name and address, the title of the series and the ISBN quoted above.

Customer Services Department, Macmillan Distribution Ltd, Houndmills, Basingstoke, Hampshire RG21 6XS, England 


\section{Love, Marriage and Intimacy among Gujarati Indians}

\section{A Suitable Match}

Katherine Twamley

John Adams Research Fellow, University of London, UK 


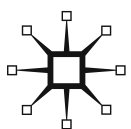

(c) Katherine Twamley 2014

Softcover reprint of the hardcover 1st edition 2014 978-1-137-29429-6

All rights reserved. No reproduction, copy or transmission of this publication may be made without written permission.

No portion of this publication may be reproduced, copied or transmitted save with written permission or in accordance with the provisions of the Copyright, Designs and Patents Act 1988, or under the terms of any licence permitting limited copying issued by the Copyright Licensing Agency, Saffron House, 6-10 Kirby Street, London EC1N 8TS.

Any person who does any unauthorized act in relation to this publication may be liable to criminal prosecution and civil claims for damages.

The author has asserted her right to be identified as the author of this work in accordance with the Copyright, Designs and Patents Act 1988.

First published 2014 by

PALGRAVE MACMILLAN

Palgrave Macmillan in the UK is an imprint of Macmillan Publishers Limited, registered in England, company number 785998, of Houndmills, Basingstoke, Hampshire RG21 6XS.

Palgrave Macmillan in the US is a division of St Martin's Press LLC, 175 Fifth Avenue, New York, NY 10010.

Palgrave Macmillan is the global academic imprint of the above companies and has companies and representatives throughout the world.

Palgrave ${ }^{\circledR}$ and Macmillan ${ }^{\circledR}$ are registered trademarks in the United States, the United Kingdom, Europe and other countries.

ISBN 978-1-349-45148-7

DOI $10.1057 / 9781137294302$

This book is printed on paper suitable for recycling and made from fully managed and sustained forest sources. Logging, pulping and manufacturing processes are expected to conform to the environmental regulations of the country of origin.

A catalogue record for this book is available from the British Library.

A catalog record for this book is available from the Library of Congress.

Typeset by MPS Limited, Chennai, India. 
For Ricardo 


\section{Contents}

Series Editors' Preface viii

Acknowledgements $\quad \mathrm{x}$

Note on Translation and Transcription xii

Preface xiii

1 Introduction 1

2 Interactions in the 'Field' 18

3 Parental Authority, Youth Autonomy and Marital Decisions 51

4 Pathways to Marriage $\quad 67$

5 Love 96

6 Gender 118

$\begin{array}{llr}7 & \text { Conclusions } & 148\end{array}$

Appendix 1: Participants' Characteristics 164

Appendix 2: Data Analysis Procedures 167

Appendix 3: Participants' Ranking 169

Appendix 4: Matrimonial and Dating Agency Materials 172

$\begin{array}{ll}\text { Notes } & 180\end{array}$

$\begin{array}{lc}\text { References } & 184\end{array}$

$\begin{array}{ll}\text { Index } & 195\end{array}$ 


\section{Series Editors' Preface}

The remit of the Palgrave Macmillan Studies in Family and Intimate Life series is to publish major texts, monographs and edited collections focusing broadly on the sociological exploration of intimate relationships and family organisation. As editors we think such a series is timely. Expectations, commitments and practices have changed significantly in intimate relationship and family life in recent decades. This is very apparent in patterns of family formation and dissolution, demonstrated by trends in cohabitation, marriage and divorce. Changes in household living patterns over the last 20 years have also been marked, with more people living alone, adult children living longer in the parental home and more 'non-family' households being formed. Furthermore, there have been important shifts in the ways people construct intimate relationships. There are few comfortable certainties about the best ways of being a family man or woman, with once conventional gender roles no longer being widely accepted. The normative connection between sexual relationships and marriage or marriage-like relationships is also less powerful than it once was. Not only is greater sexual experimentation accepted, but is also now accepted at an earlier age. Moreover, heterosexuality is no longer the only mode of sexual relationship given legitimacy. In Britain as elsewhere, gay male and lesbian partnerships are now socially and legally endorsed to a degree hardly imaginable in the mid-twentieth century. Increases in lone-parent families, the rapid growth of different types of stepfamily, the de-stigmatisation of births outside marriage and the rise in couples 'living-apart-together' (LATs) all provide further examples of the ways that 'being a couple', 'being a parent' and 'being a family' have diversified in recent years.

The fact that change in family life and intimate relationships has been so pervasive has resulted in renewed research interest from sociologists and other scholars. Increasing amounts of public funding have been directed to family research in recent years, in terms of both individual projects and the creation of family research centres of different hues. This research activity has been accompanied by the publication of some very important and influential books exploring different aspects of shifting family experience, in Britain and elsewhere. The Palgrave Macmillan Studies in Family and Intimate Life series hopes to add to this list of influential research-based texts, thereby contributing to existing 
knowledge and informing current debates. Our main audience consists of academics and advanced students, though we intend that the books in the series will be accessible to a more general readership who wish to understand better the changing nature of contemporary family life and personal relationships.

We see the remit of the series as wide. The concept of 'family and intimate life' will be interpreted in a broad fashion. While the focus of the series will clearly be sociological, we take family and intimacy as being inclusive rather than exclusive. The series will cover a range of topics concerned with family practices and experiences, including, for example, partnership; marriage; parenting; domestic arrangements; kinship; demographic change; intergenerational ties; life course transitions; stepfamilies; gay and lesbian relationships; lone-parent households; and also non-familial intimate relationships such as friendships. We also wish to foster comparative research, as well as research on under-studied populations. The series will include different forms of book. Most will be theoretical or empirical monographs on particular substantive topics, though some may also have a strong methodological focus. In addition, we see edited collections as also falling within the series' remit, as well as translations of significant publications in other languages. Finally we intend that the series has an international appeal, in terms of both topics covered and authorship. Our goal is for the series to provide a forum for family sociologists conducting research in various societies and not solely in Britain.

Graham Allan, Lynn Jamieson and David Morgan 


\section{Acknowledgements}

Thanks are due first to Ann Oakley, who has been the kind of mentor I always dreamed of having. Ann has guided and encouraged me while writing this book, and her participation has greatly improved the pages that follow. I have been so privileged to work with you and I hope to continue doing so, if you'll let me.

Many others have contributed to this project. Anthony Pryce and Karina Kielmann guided and advised me on the research from the early days of ill-thought out research questions. Very special thanks should also go to Peter Martin, who gave meticulous and perceptive comments on an early draft. I am also grateful to Les Back, John Solomos, Edward Simpson, Susan Richards, Paul Godin, Eamonn McKeown, Holly Wardlow and Henrike Donner for their observations and comments on this work. Any faults that remain are entirely my own.

However, none of this would have come to pass without the generous participation of the numerous men and women whose narratives fill these pages. Because of the need to protect confidentiality I cannot thank them by name, but I send them my heartfelt thanks for inviting me into their homes and lives. I am especially grateful to my wonderful fun-loving flatmate and my incredibly kind and generous Gujarati language teacher in Baroda. Our endless conversations on love, relationships and marriage helped me more than you can ever know. I miss you both. My fieldwork experiences in Baroda and London were eased by many others, most especially Aruna Shah and Parul Dave who welcomed me into their homes when I was far from my own. Thanks also to Hasan Algawasmeh, Tanja Auras and Katie Lindstrom for endless cups of chai in the lovely Chaipuri. I am also grateful to my assistant in Baroda Amit Mehta.

Throughout the last few years I have been fortunate to have the support of some wonderful friends and colleagues. Thank you especially to Kate Hinds, Kate Devlin, Robert Cuffe, Ana Llamas, Lauren Bardisa, Monica Rabanillo, Sipke Visser, Rocio Gomez, Alessia Annibale, Conn O'Connor, Alan O'Sullivan, Sarah Duff and Isabelle Hertner for the judiciously timed library breaks and fun-filled nights. Thanks also to colleagues at City University, especially Alison Macfarlane and the members of the City University Research Student Support Group, colleagues in the London School of Hygiene, UCL, especially Myra Bluebond-Langner 
for her unwavering confidence in me, and the Institute of Education. Many thanks to St Bartholomew's and the Royal London Charitable Foundation which funded the research and the Economic and Social Research Council, who funded my time while writing this book.

But even with all this support, I would never even have considered undertaking this career path were it not for the support of my parents and the unrelenting faith and encouragement of my sister Sarah and her wonderful wife Leeanne.

Finally, my thanks go to Ricardo Grau Crespo, to whom I dedicate this book. While I mused on the nature of love, he showed me what it is to be in love. A more generous and supportive companion could not be found; truly this book would not have been possible without you. 


\section{Note on Translation and Transcription}

The majority of the interviews and conversations undertaken as part of the data collection in this book were conducted in English. Where conversations were translated or conducted with an interpreter this is indicated in the text, including which parts of the conversation were translated and which were conducted in English.

Participants had different standards of fluency in English. In (re)presenting their accounts, extracts from recorded interviews have not been edited or 'tidied up' in any way. Words are presented as they were spoken, including grammatical errors, laughter and pauses. A beat pause is indicated by . Two beats by .. And so on. Alternatively the time of silence is recorded in square parentheses [3 seconds]. Other nonverbal forms of communication are also indicated in square parentheses for example [laugh]. Parts of a quote edited because they are not directly relevant to the discussion are indicated by [...]. When two people overlap in speech / is used to indicate the moment of overlap. For example:

\section{A: I went to / the shop \\ B: /we go every day}

Where 'the shop' and 'we go' were spoken at the same time. These approaches to the presentation of data are used to allow the reader (and researcher) to experience as much as possible the 'feel' of the interview and the flow of conversation between researcher and researched (see Sandelowski 1994). 


\section{Preface}

In 2002 I took a gap year after my undergraduate degree and, like many students before me, I went to India. But while others headed to the cool mountains of Shimla, the humid backwaters of Kerala or the beautiful beaches of Goa, I went to Baroda in Gujarat to work for an international non-governmental organization (NGO). Baroda is not a common destination for travellers. In many ways it is a non-descript city. With around two million people, it is neither big nor small. There are no tourist attractions to speak of, few beaches to bathe on and, perhaps more importantly (for some), Gujarat is the only state in India where alcohol is illegal. I knew none of this when I headed there, for actually I had requested a placement in French-speaking Africa, and if it wasn't for some glitch in computer or administrative procedure I would never have gone to Baroda.

I spent a year in India on that first trip, six months of which were in Baroda. Those six months were formative in sowing the seeds of this research project. It was nothing to do with the NGO, although that work was interesting, I was more intrigued by the friends I made and the conversations we had (frequently) about love, marriage and sex. To my surprise, my Gujarati friends had very different notions and ideas of love; until that time I thought love was a universal emotion and marriage its common culmination. My friends showed me otherwise.

One such friend was Antuk. Antuk spoke with me incessantly about his dreams of falling in love and his expectations and curiosity about sex. He was fascinated by 'western' culture, and told me he wished for a more open and modern India in which young people could date and court more freely. Eager to support such a romantic, I encouraged him to ask a girl out. To my surprise he asked out my Icelandic colleague Jane. Jane was as surprised as I was, but she accepted in the name of cultural curiosity. Afterwards she described their date to me: Antuk arrived to pick her up in a chauffeur driven car with roses, chocolates and a bottle of cola waiting for her inside. He ceremoniously poured the cola into two champagne glasses and they headed to the movies. After the cinema (a romantic Bollywood film) he brought her out for coffee and dessert, then promptly brought her home by ten p.m. Jane described the date as 'film-like' in its romanticism. She enjoyed the date, but felt overwhelmed by Antuk's romantic attentions. Antuk told 
me that he enjoyed the date too but that he had decided not to ask her out again: he knew their relationship could never lead to marriage and Jane seemed too nice to have a 'time pass' (fling) relationship with. I asked him why could he not marry Jane. He looked at me aghast; she was a foreigner and anyway he fully intended to have an arranged marriage. His parents had already started looking for a wife for him.

Four months later, Antuk was engaged to an American-born Gujarati girl, Leela. Antuk and Leela met once briefly when she and her family flew over to Baroda to finalise the wedding arrangements. At that time he told me that he loved Leela and was 'dying' to marry her. While I never really got a chance to speak with her, he told me that she felt the same way. After the wedding, Antuk moved to New Jersey where his wife was from. He wrote to me soon after that his wife insisted on bringing him breakfast in bed every morning. She was everything he ever wanted.

Antuk's story shook me on many levels. I found the story of his marriage with Leela incompatible with his earlier pronouncements of the importance of love and romance. I also couldn't understand why he felt that he should have an arranged marriage, or even why he would want one. But finally, Leela, who had been brought up in the US, dumbfounded me. How could someone with an upbringing ostensibly similar to mine (or at least I assumed it was) ultimately have an arranged marriage to a man she barely knew? (And why on earth was she bringing him breakfast in bed every morning?)

Such ambiguities and questions were frequent. I found that many of my friends in Baroda both idealised romantic love, and wanted to have an arranged marriage. They seemed to have a strong ambivalence towards 'western culture' and romance, which both enticed and repelled them. Young people wanted changes, but these changes seemed unclear and sometimes conflicting.

These ambiguities and questions led me to this project. I returned to Baroda in 2006 and, using an ethnographic approach, spent nine months collecting the relationship views and experiences of heterosexual men and women aged between 20 and 30 years old. I interviewed newly married and unmarried men and women, and some older participants too, such as parents and matchmakers. I 'hung out' with old friends and sought out new people who could tell me their perspectives on love and marriage in a more systematic way. With pages of field notes and recorded interviews, I then returned to London and conducted similar fieldwork with Gujaratis brought up and living in the UK. Such a comparison allowed me to unpack how being brought up 'Gujarati' but in the UK or a rapidly modernising India impacts on relationship and 
marriage trajectories. My interest was sparked by 'love' and its meaning to young people in Baroda - and this theme is explored in the pages that follow - but this book can also be viewed as a case study of the effects of globalisation and transnationalism. How are global ideologies (of love and romance) interpreted and lived out in two very different settings by members of the same cultural ethnic group? Through comparing the narratives of Gujaratis in these different contexts, A Suitable Match explores how global discourses are interpreted and transformed. Such a comparison illustrates how intimate life, that seemingly most personal aspect of human practice, is shaped by the cultural and socio-economic circumstances in which people live.

While there is a growing body of research on middle class identity in India, this is, so far as I am aware, the first book to explore the particular marriage ideals and experiences of middle class Gujaratis in two different cultural contexts. The sample studied in London, of second generation Gujaratis, is timely, since most second generation Indians are now reaching an age where they are marrying and creating families. How they negotiate the multiple cultural influences of their parents and peers to create new forms of being and relating with one another is therefore of increasing interest. Marriage is a central issue in this process, acting as a means of (re)producing collective identity by providing continuity between generations.

In the pages that follow, through exploring stories such as Antuk's, I will show that ideologies of romantic love and companionate marriage are pervasive at a global level, but these global forms take on particular hybrid versions as they intersect with local understandings of emotional life. This will be of interest to scholars of Indian culture, intimacy more generally, and globalisation and its processes. 